УДК 347.9

DOI https://doi.org/10.32849/2663-5313/2019.5.13

\title{
Марія Шевелуха,
}

студентка юридичного факультету

Дніпропетровського державного університету внутрішніх справ

\section{ЗАОЧНИЙ РОЗГЛЯД СПРАВИ В ЦИВІЛЬНОМУ ПРОВАДЖЕННІ}

У статті розкривається порядок заочного розгляду справи в ицвільному провадженні за законодавством України. Розглядаються особливості заочного розгляду справи в цивільному провадженні. Автор розкриває умови заочного провадження справ у судах.

Ключові слова: суд, справа, заочне рішення, заочний розгляд, перегляд заочного рішення.

Постановка проблеми. Прийняття Закону України «Про внесення змін до Господарського процесуального кодексу України, Цивільного процесуального кодексу України, Кодексу адміністративного судочинства України та інших законодавчих актів», що набуло чинності 15.12.2017, стало важливим етапом на шляху вдосконалення вітчизняного процесуального законодавства, механізму судового захисту й посилення змагальних засад господарського судочинства.

Україна впевнено крокує до досягнення мети щодо отримання вищого статусу правової держави, яка має у своєму розпорядженні нове, прогресивне законодавство, постійно здійснюе пошуки й утілює нові сучасні методи, спрямовані на дотримання й захист прав і свобод людини. Одним із таких кроків є судово-правова реформа, що нині триває. Однак поряд із цим існує багато інших проблем у цій царині.

Проблема розгляду справи в цивільному провадженні була предметом дослідження багатьох науковців і вчених-процесуалістів, зокрема таких як С.С. Бичкова, С.В. Васильєв, П.Ф. Єлісейкін, В.В. Комаров, С.Я. Фурса, С.І. Фурса, Ю.С. Червоний, Д.М. Чечот, М.С. Шакарян та ін. Зазначені науковці зробили вагомий внесок у дослідження питань особливостей розгляду справи в цивільному провадженні. Однак деякі проблемні моменти залишаються дослідженими досить поверхово, що й зумовлює актуальність дослідження в цьому напрямі.

Актуальність зумовлена тим, що виконання завдань цивільного судочинства залежить від правильного застосування цивільним судом норм матеріального та процесуального права. У цьому розрізі первинним напрямом є розгляд справи в цивільному провадженні. Тематика роботи актуалізується в контексті сучасних євроінтеграційних процесів України, зокрема особливого значення набувають питання щодо визначення сутності й значення розгляду справи в цивільному провадженні.
Метою статті є з'ясування особливостей заочного розгляду справи в цивільному провадженні.

Виклад основного матеріалу. 3 метою врегулювання процесуальних механізмів, які мають забезпечити ефективний, справедливий, неупереджений і своєчасний захист прав і свобод особи в суді, 23 березня 2017 року Президентом України подано до Верховної Ради України Проект Закону України «Про внесення змін до Господарського процесуального кодексу України, Цивільного процесуального кодексу України, Кодексу адміністративного судочинства України та інших законодавчих актів» (реєстр. номер 6232), який 3 жовтня 2017 року прийнято як Закон України [1]. Для досягнення цієї мети Законом викладаються в новій редакції Господарський процесуальний кодекс України (далі - ГПК), Цивільний процесуальний кодекс України (далі - ЦПК), Кодекс адміністративного судочинства України (далі - КАС) й уносяться зміни до законодавчих актів.

Загалом прийняття цього Закону є важливим кроком України в напрямі розвитку сучасних демократичних європейських держав. Крім того, ГПК, ЦПК та КАС містять новели для науки й законодавства України, які вже є предметом обговорення та дослідження.

Заочне провадження або заочний розгляд справи став можливим у сучасному цивільному процесі після прийняття ЦПК у 2004 році. Інститут заочного розгляду не $є$ новелою ЦПК, він поновлений у зв'язку зі зміною змісту цивільних процесуальних правовідносин [2, с. 164].

Уведення інституту заочного розгляду справи покликано реалізувати Рекомендацію № R (84) 5 Комітету Міністрів Ради Свропи державам-членам стосовно принципів цивільного судочинства, що спрямо- 
вані на вдосконалення судової системи. Для досягнення цієї мети необхідно забезпечити доступ сторін до спрощених і більш оперативних форм судочинства (до яких належить заочний розгляд) і захистити їх від зловживань і затримок, зокрема надавши суду повноваження здійснювати судочинство більш ефективно [3, с. 455].

Інститут заочного рішення спрямований, з одного боку, на розширення засад диспозитивності в цивільному процесі (зокрема свободи розсуду сторін), та, з іншого боку, на запобігання можливості зловживання процесуальними правами й установлення відповідальності за ці зловживання [4, с. 148]. 3 огляду на це, заочне провадження правильно розглядати як надання додаткових процесуальних гарантій позивачеві, який так набуває захисту від несумлінного відповідача, що, зловживаючи своїми процесуальними правами, не з'являється до судового засідання та затягує розгляд справи. Крім досягнення процесуальної економії, заочне провадження має на меті дисциплінувати тих відповідачів, які фактично перешкоджають ухваленню рішення у справі.

До того ж у юридичній літературі заочне провадження називають спрощеною процедурою або вважають спрощеним через відсутність відповідача під час розгляду справи й тих обмежень, що встановлені для позивача [4, c. 148$]$

Главою 11 розділу ІІІ ЦПК регламентується інститут заочного рішення, яке визначається як рішення, що ухвалюється судом у разі неявки в судове засідання відповідача, який належним чином повідомлений і від якого не надійшло повідомлення про причини неявки або зазначені ним причини визнані неповажними та якщо позивач не заперечує проти такого вирішення справи [5].

Загалом реалізація інституту заочного провадження в цивільно-процесуальному законодавстві України не позбавлена недоліків, що іноді призводить до суттєвого порушення прав і законних інтересів однієї або обох сторін. Із моменту виникнення інституту заочного розгляду в ЦПК він зазнав істотної трансформації.

Аналіз положень ЦПК щодо заочного розгляду справи дає змогу дійти висновку, що зазначений інститут потребує серйозного доопрацювання, а практика перегляду та виконання заочних рішень свідчить про існування системних проблем.

Загальні засади заочного провадження передбачені ст. ст. 280-289 ЦПК. Відповідно до ст. 280 цього Кодексу, у разі неявки в судове засідання відповідача, який належним чином повідомлений і від якого не надійшло заяви про розгляд справи за його відсутності або якщо повідомлені ним причини неявки визнані неповажними, суд може ухвалити заочне рішення на підставі наявних у справі доказів, якщо позивач не заперечує проти такого вирішення справи.

Так, згідно 3 ч. 1 ст. 280 ЦПК, суд може ухвалити заочне рішення на підставі наявних у справі доказів за одночасного існування таких умов: 1) відповідач належним чином повідомлений про дату, час і місце судового засідання; 2) відповідач не з'явився в судове засідання без поважних причин або без повідомлення причин; 3) відповідач не подав відзив; 4) позивач не заперечує проти такого вирішення справи.

Отже, законодавством передбачено сукупність чотирьох умов, які дають можливість суду ухвалити заочне рішення: 1) відповідач належним чином повідомлений про дату, час і місце судового засідання; 2) відповідач не з'явився в судове засідання без поважних причин або без повідомлення причин; 3) відповідач не подав відзив; 4) позивач не заперечує проти такого вирішення справи.

Законодавчо не врегульованими $є$ правомочності суду щодо випадків незгоди позивача на заочний розгляд справи.

Суд не правомочний ухвалити заочне рішення в разі явки в судове засідання представника відповідача 3 належно оформленими повноваженнями. При цьому саме надмірні сподівання на представника нерідко призводять до ухвалення заочних рішень. У такому випадку відповідач впевнений у тому, що його представник з'являється в судові засідання, а цього насправді не відбувається. Неявка представника відповідача може стати додатковою підставою для скасування заочного рішення.

ЦПК передбачає особливий порядок оскарження заочного рішення. Зокрема, відповідно до ст. 284 ЦПК, заочне рішення може бути переглянуте судом, що його ухвалив, на підставі заяви відповідача. У разі залишення заяви про перегляд заочного рішення без задоволення не виключається можливість оскарження заочного рішення відповідачем у загальному порядку шляхом подання апеляційної скарги.

Згідно зі ст. 288 ЦПК, заочне рішення підлягає скасуванню, якщо судом буде встановлено, що відповідач не з'явився в судове засідання та не повідомив про причини неявки 3 поважних причин, і докази, на які він посилається, мають істотне значення для правильного вирішення справи. Для скасування заочного рішення необхідна наявність обох передбачених ст. 280 ЦПК обставин.

Аналіз ЦПК дає змогу дійти висновку про існування системних проблем під час реалі- 
зації інституту заочного розгляду справи в цивільному судочинстві. Зокрема, серед основних із них можна виділити такі: непоодинокі випадки ухвалення заочних рішень у справах, де відповідач не був повідомлений належним чином про судові засідання, що призводить до суттєвого порушення інтересів відповідача; відсутність єдиної практики набрання заочним рішенням законної сили через прогалини в ЦПК; порушення інтересів позивача, через те що не визначено натепер, як діяти суду, якщо копію заочного рішення неможливо вручити відповідачу з тих чи інших причин; визнання заочного рішення таким, що набрало законної сили після спливу десяти днів з дня його проголошення, і звернення його до примусового виконання; наявність хибної практики зупинення стягнення за виконавчим документом, що за своєю сутністю є заходом забезпечення позову, аналогією закону, відповідно до якої до заяви про перегляд заочного рішення застосовуються загальні норми ЦПК; відсутність законодавчо визначених підстав визнання виконавчого листа таким, що не підлягає виконанню [6, с. 172-173].

Істотною відмінністю заочного рішення від звичайного $є$ можливість спрощеного порядку його перегляду самим судом, що ухвалив таке рішення за заявою відповідача. Так, згідно зі ст. 284 ЦПК, заочне рішення може бути переглянуте судом, що його ухвалив, за письмовою заявою відповідача. Однак у зазначеній статті не вказано, що робити суду, якщо такий строк пропущено за будь-яких причин. Тому вважаємо за доцільне закріпити положення, яке дало б змогу поновити такий строк, якщо причини пропуску такого строку будуть визначені судом поважними.

\section{Висновки}

Під час розгляду справи в порядку заочного провадження суд досліджує докази, подані сторонами, враховує їхні доводи, міркування та клопотання й ухвалює рішення, що є заочним. Однак відсутність у судовому засіданні відповідача та неможливість заслухати його пояснення ще зовсім не означає, що позовні вимоги позивача будуть задоволені в повному обсязі, оскільки суд розглядає справу на підставі наявних у справі доказів і в разі недоведеності позову повинен відмовити в позові або задовольнити його лише в доведеній позивачем частині.
Наявність заочного розгляду справи в цивільному провадженні на шляху реформування судової системи є важливим кроком у побудові європейської моделі юстиції. Формування в Україні правової держави та громадянського суспільства безпосередньо пов'язано з проблемою створення належного механізму забезпечення прав і свобод людини та громадянина. Судові органи в цьому аспекті є гарантом у забезпеченні таких прав, тому потребують реформування 3 метою створення сильного й дієвого механізму правового захисту.

Упровадження заочного розгляду справ, безумовно, є ще однією гарантією для розширення засад диспозитивності в цивільному процесі (зокрема свободи розсуду сторін), 3 іншого боку, спрямоване на запобігання можливості зловживання процесуальними правами й установлення відповідальності за ці зловживання. Однак, попри це, існують певні недоліки та неточності, які потребують свого вирішення й удосконалення. Тому для цього має бути підготовлений і внесений цілий комплекс прозорих науково вироблених i науково обгрунтованих пропозицій щодо вдосконалення заочного розгляду справ.

\section{Список використаних джерел:}

1. Про внесення змін до Господарського процесуального кодексу України, Цивільного процесуального кодексу України, Кодексу адміністративного судочинства України та інших законодавчих актів: Закон України від 03.10.2017 (зі змінами і допов.). Відомості Верховної Ради України. 2017. № 96. Ст. 2921.

2. Устінова-Бойченко Г.М. Процесуальні наслідки прийняття позивачем рішення про заочний розгляд справи. Європейські перспективи. 2012. № 2 (1). С. 163-166.

3. Цивільне процесуальне право України: підручник / С.С. Бичкова, I.А. Бірюков, В.І. Бобрик та ін.; за заг. ред. С.С. Бичкової. Київ: Атіка, 2009. $760 \mathrm{c}$.

4. Горбонос Ф.В., Іващук Н.Л. Поняття та умови заочного провадження справ у судах. Hayкові записки Львівського університету бізнесу та права. 2012. Вип. 8. С. 147-151.

5. Цивільний процесуальний кодекс України від 18.03.2004 (в редакції від 07.12.2017). Відомості Верховної Ради України. 2004. № 40. Ст. 492.

6. Трипольська M.I. Проблемні питання реформування ради безпеки ООН. Держава та регіони. Серія «Право». 2014. № 4. С. 172-174. 
В статье раскрывается порядок заочного рассмотрения дела в гражданском производстве по законодательству Украинь. Рассматриваются особенности заочного рассмотрения дела в гражданском производстве. Автор раскрывает условия заочного производства дел в судах.

Ключевые слова: суд, дело, заочное решение, заочное рассмотрение, пересмотр заочного решения.

The article reveals the procedure of correspondence consideration of a case in civil proceedings under the legislation of Ukraine. The peculiarities of extra-judicial consideration of a case in civil proceedings are considered. The author disclose the terms of correspondence proceedings in courts.

Key words: court, case, part-time decision, correspondence examination, review of an out-of-date decision. 